\title{
In Our Best Interest: Women, Financial Literacy, and Credit Card Behavior
}

\author{
Gary R. Mottola
}

Financial Industry Regulatory Authority, gary.mottola@finra.org

\section{Recommended Citation}

Mottola, Gary R.. "In Our Best Interest: Women, Financial Literacy, and Credit Card Behavior." Numeracy 6, Iss. 2 (2013): Article 4. DOI: http://dx.doi.org/10.5038/1936-4660.6.2.4 


\title{
In Our Best Interest: Women, Financial Literacy, and Credit Card Behavior
}

\begin{abstract}
Data from the FINRA Investor Education Foundation's National Financial Capability Study revealed that women were more likely to engage in costly credit card behaviors-like incurring late and over-the-limit fees--than men. After controlling for a number of demographic variables, including financial literacy and a self-assessment of mathematical ability, the gender-based differences in credit card behavior were eliminated. These findings suggest that credit card management differences between the sexes could be reduced if parity existed between men and women on important variables that women tend to trail men on, such as income and financial literacy.
\end{abstract}

\section{Keywords}

financial literacy, gender, credit cards

Creative Commons License

(c) (1) (9)

This work is licensed under a Creative Commons Attribution-Noncommercial 4.0 License

\section{Cover Page Footnote}

Gary R. Mottola is the Research Director of the FINRA Investor Education Foundation. He completed his $\mathrm{PhD}$ in Social Psychology at the University of Delaware. 


\section{Introduction}

Women consistently score lower than men on financial literacy measures, and this gender-based gap may negatively impact the financial well-being of women (Fonseca et al. 2012). For example, financial literacy has been linked to a number of important outcomes, including wealth accumulation (Stango and Zinman 2009), stock market participation (van Rooij et al. 2011; Yoong 2011), and retirement planning (Lusardi and Mitchell 2008). So, the lower levels of financial literacy among women may be impeding their ability to accumulate and manage assets and, ultimately, secure a promising financial future.

Women may face some challenges on the debt side of the financial equation, as well. Lusardi and Tufano (2009) found that women tend to have lower "debt literacy” levels than men and engage in more high-cost methods of borrowingsuch as using payday lenders, pawn shops, and rent-to-own stores. Consistent with this finding, Allgood and Walstad (2011) reported that women under age 60 tend to engage in more costly credit card behaviors than men, such as carrying a balance on their credit cards and incurring late payment fees.

Improving our understanding of credit card behavior among women is particularly important because credit cards are so pervasive in the United States. According to US Census data, 70\% of families use credit cards, and, on average, cardholders have seven cards (US Census Bureau 2012). Further, the Federal Reserve reports an average balance of $\$ 7,700$ among cardholders with outstanding balances (Bricker et al. 2012). Given such widespread use, credit card mismanagement can have far-reaching effects. Missed and late payments, large balances, and exceeding credit limits can lead to higher fees, higher interest rates, and lower credit scores. Similarly, failing to choose a card with a competitive interest rate and reasonable features can drive up borrowing costs.

This paper further explores the relationships among credit card behavior, gender, and financial literacy. It also takes an exploratory look at the association between gender and credit card interest rates. A more nuanced understanding of these relationships could help identify areas that might benefit from additional research and help practitioners and policymakers allocate limited financial education resources to groups and areas most in need.

\section{Data}

This study uses data from the State-by-State version of the 2009 National Financial Capability Study (NFCS). The goal of the NFCS is to benchmark and better understand financial capability in America. It was funded by the Financial Industry Regulatory Authority (FINRA) Investor Education Foundation and 
conducted by Applied Research and Consulting. The NFCS was developed in consultation with the US Department of the Treasury and President Bush's Advisory Council on Financial Literacy. The survey was conducted using a sample of 28,146 adults age 18 and older (approximately 500 per state plus the District of Columbia) obtained from Research Now and SSI via proprietary, online panels of individuals who have agreed to participate in the panel and who are compensated for completing surveys. Nonprobability quota sampling was used to obtain the sample, and the sample has been weighted to be representative of the US adult population (age 18 and up) on age by gender, ethnicity, education, and census division-data from the US Census Bureau's 2008 American Community Survey were used to construct the weights. Data collection ran from June to October 2009, and the average time respondents took to complete the survey was fifteen minutes.

The NFCS contains over 130 questions spread out over five general sections. The demographic section contains questions that assess age, gender, income, marital status, education level, minority status, living arrangements, employment status, and dependents. The rest of the survey focuses on four key components of financial capability-making ends meet, planning ahead, managing financial products, and financial knowledge and decision-making The survey also includes a self-assessment of mathematical ability. The full NFCS questionnaire is available at www.USFinancialCapability.org, and a comprehensive overview of the NFCS data is provided in Lusardi (2011).

The 2009 NFCS data have been widely used by academic and government researchers exploring a variety of financial capability topics. For example, articles that have examined financial advice, financial literacy and retirement planning, international differences in financial literacy, and financial knowledge scales have been published in peer-reviewed journals. ${ }^{1}$ The data have been used in well over a dozen white papers and issue briefs, and statistics from the study have been widely cited by a variety of major media outlets including the Wall Street Journal, US News and World Report, and the Today show to name a few. Further, output from the project has been used in government reports and in congressional testimony. $^{2}$

As noted, the NFCS includes questions that span a broad array of financial knowledge and behavior-including five financial literacy questions and six questions on credit card behavior, all of which are listed below.

\footnotetext{
${ }^{1}$ See Robb et al. (2012); Lachance and Tang (2012); Collins (2012); Knoll and Houts (2012); Lusardi and Mitchell (2011a, 2011b); and Robb and Woodyard (2011).

${ }^{2}$ See www.FinancialCapability.org for a list of white papers, issue briefs, government reports, and congressional testimony that use the data.
} 


\section{Interest Rate Question}

1. Suppose you had $\$ 100$ in a savings account and the interest rate was $2 \%$ per year. After 5 years, how much do you think you would have in the account if you left the money to grow?
A. More than $\$ 102$
B. Exactly $\$ 102$
C. Less than $\$ 102$
D. Don't know
E. Prefer not to say

\section{Inflation Question}

2. Imagine that the interest rate on your savings account was $1 \%$ per year and inflation was $2 \%$ per year. After 1 year, how much would you be able to buy with the money in this account?
A. More than today
B. Exactly the same
C. Less than today
D. Don't know
E. Prefer not to say

\section{Risk Question}

3. Buying a single company's stock usually provides a safer return than a stock mutual fund.
A. True
B. False
C. Don't know
D. Prefer not to say

\section{Bond Price Question}

4. If interest rates rise, what will typically happen to bond prices?
A. They will rise
B. They will fall
C. They will stay the same
D. There is no relationship between bond prices and the interest rate
E. Don't know
F. Prefer not to say

\section{Mortgage Question}

5. A 15-year mortgage typically requires higher monthly payments than a 30-year mortgage, but the total interest paid over the life of the loan will be less.
A. True
B. False
C. Don't know
D. Prefer not to say 


\section{Credit Card Behavior}

In the past 12 months, which of the following describes your experience with credit cards? (Select an answer for each). Note:

Available responses included yes, no, don't know, and prefer not to

say.

1. I always paid my credit cards in full.

2. In some months, I carried over a balance and was charged interest.

3. In some months, I paid the minimum payment only.

4. In some months, I was charged a late fee for late payment.

5. In some months, I was charged an over the limit fee for exceeding my credit line.

6. In some months, I used the cards for a cash advance.

Three of the financial literacy questions - the interest rate, inflation, and risk questions - were originally designed by Lusardi and Mitchell for inclusion in the 2004 Health and Retirement Study (Lusardi and Mitchell 2011c). The question on bond pricing was also developed by Lusardi (in collaboration with Rob Alessie and Maarten van Rooij) for inclusion in the Dutch Central Bank Household Survey, and later in the RAND American Life Panel, and can be used to differentiate respondents with very high levels of financial literacy from those with average levels of financial literacy. The mortgage question was developed for the 2009 National Financial Capability Study because the FINRA Investor Education Foundation-the sponsor of the study-was interested in understanding Americans' knowledge about mortgages. Over the last several years, these financial literacy questions have been frequently used by researchers to measure financial literacy. ${ }^{3}$ The six questions used to assess credit card behavior are slightly modified versions of the credit card behavior questions used by Lusardi and Tufano (2009).

Table 1 shows detailed information about the sample used in this analysis. Compared to men, women in the sample tend to be slightly older-for example, $17 \%$ of women are age 65 or older compared to $13 \%$ of men. Women also tend to have lower household incomes-43\% have less than \$35,000 in household income compared to $37 \%$ for men, and only $22 \%$ have over $\$ 75,000$ in household income compared to $27 \%$ for men. Further, women are also somewhat less likely to be college educated, $23 \%$ of female respondents have a college degree or postgraduate education compared to $28 \%$ of male respondents. ${ }^{4}$

\footnotetext{
${ }^{3}$ See Knoll and Houts (2012).

${ }^{4}$ Census data show the education gap narrowing since the 1970s for Americans age 25 and older, and as of 2010 parity nearly exists on this measure (US Census 2012).
} 
Table 1

Sample Characteristics

\begin{tabular}{|c|c|c|c|}
\hline & Total & Male & Female \\
\hline Unweighted Sample Size & 28,146 & 13,168 & 14,978 \\
\hline \multicolumn{4}{|l|}{ Age } \\
\hline$\overline{18-24}$ & $14 \%$ & $14 \%$ & $13 \%$ \\
\hline $25-29$ & $8 \%$ & $8 \%$ & $8 \%$ \\
\hline $30-34$ & $9 \%$ & $10 \%$ & $8 \%$ \\
\hline $35-39$ & $9 \%$ & $9 \%$ & $9 \%$ \\
\hline $40-44$ & $10 \%$ & $10 \%$ & $9 \%$ \\
\hline $45-49$ & $9 \%$ & $9 \%$ & $9 \%$ \\
\hline $50-54$ & $11 \%$ & $11 \%$ & $10 \%$ \\
\hline $55-59$ & $9 \%$ & $9 \%$ & $10 \%$ \\
\hline $60-64$ & $7 \%$ & $7 \%$ & $7 \%$ \\
\hline 65 or older & $15 \%$ & $13 \%$ & $17 \%$ \\
\hline \multicolumn{4}{|l|}{ Household Income } \\
\hline Less than $\$ 15,000$ & $15 \%$ & $14 \%$ & $15 \%$ \\
\hline$\$ 15,000$ to $\$ 25,000$ & $13 \%$ & $12 \%$ & $14 \%$ \\
\hline$\$ 25,000$ to $\$ 35,000$ & $13 \%$ & $11 \%$ & $14 \%$ \\
\hline$\$ 35,000$ to $\$ 50,000$ & $16 \%$ & $15 \%$ & $17 \%$ \\
\hline$\$ 50,000$ to 75,000 & $19 \%$ & $20 \%$ & $18 \%$ \\
\hline$\$ 75,000$ to $\$ 100,000$ & $11 \%$ & $13 \%$ & $9 \%$ \\
\hline$\$ 100,000$ to $\$ 150,000$ & $9 \%$ & $10 \%$ & $8 \%$ \\
\hline$\$ 150,000$ or more & $5 \%$ & $5 \%$ & $5 \%$ \\
\hline \multicolumn{4}{|l|}{ Marital Status } \\
\hline$\overline{\text { Married }}$ & $53 \%$ & $53 \%$ & $54 \%$ \\
\hline Single & $28 \%$ & $33 \%$ & $24 \%$ \\
\hline Separated & $2 \%$ & $2 \%$ & $2 \%$ \\
\hline Divorced & $12 \%$ & $10 \%$ & $14 \%$ \\
\hline Widowed/Widower & $4 \%$ & $2 \%$ & $7 \%$ \\
\hline \multicolumn{4}{|l|}{ Race } \\
\hline White & $69 \%$ & $68 \%$ & $69 \%$ \\
\hline Black & $11 \%$ & $11 \%$ & $12 \%$ \\
\hline Hispanic & $13 \%$ & $14 \%$ & $13 \%$ \\
\hline Asian & $5 \%$ & $5 \%$ & $4 \%$ \\
\hline Other & $2 \%$ & $2 \%$ & $2 \%$ \\
\hline \multicolumn{4}{|l|}{ Dependents } \\
\hline$\overline{1}$ & $16 \%$ & $15 \%$ & $17 \%$ \\
\hline 2 & $13 \%$ & $12 \%$ & $15 \%$ \\
\hline 3 & $6 \%$ & $5 \%$ & $7 \%$ \\
\hline 4 or more & $3 \%$ & $3 \%$ & $4 \%$ \\
\hline \multicolumn{4}{|l|}{ No Financially Dependent } \\
\hline Children & $30 \%$ & $28 \%$ & $33 \%$ \\
\hline Do Not Have Children & $31 \%$ & $38 \%$ & $25 \%$ \\
\hline \multicolumn{4}{|l|}{ Education } \\
\hline Did Not Complete High School & $3 \%$ & $3 \%$ & $4 \%$ \\
\hline High School Graduate & $29 \%$ & $26 \%$ & $32 \%$ \\
\hline Some College & $42 \%$ & $42 \%$ & $42 \%$ \\
\hline College Graduate & $16 \%$ & $18 \%$ & $14 \%$ \\
\hline Postgraduate Education & $9 \%$ & $10 \%$ & $9 \%$ \\
\hline Experienced an Income Shock & $41 \%$ & $39 \%$ & $43 \%$ \\
\hline
\end{tabular}




\section{Gender, Financial Literacy, and Credit Card Behavior}

Consistent with earlier studies, women score significantly lower on all the measures of financial literacy. The percentage of women getting each question correct ranged from 8 percentage points lower on the mortgage question to 16 percentage points lower on the inflation question. Also noteworthy, and also reported in earlier studies, women are much more likely to indicate that they do not know the answer to a question (Lusardi 2011). For example, women are from 1.5 to 2.0 times as likely to answer “don't know," depending on the question (Table 2).

Table 2

Financial Literacy Quiz Responses

\begin{tabular}{|c|c|c|c|c|c|c|}
\hline & \multicolumn{2}{|c|}{ Total } & \multicolumn{2}{|c|}{ Male } & \multicolumn{2}{|c|}{ Female } \\
\hline & & Don't & & Don't & & Don't \\
\hline & Correct & Know & Correct & Know & Correct & Know \\
\hline Unweighted Sample Size & \multicolumn{2}{|c|}{28,146} & \multicolumn{2}{|c|}{13,168} & \multicolumn{2}{|c|}{14,978} \\
\hline Interest Rate Question & $78 \%$ & $10 \%$ & $83 \%$ & $7 \%$ & $72 \%$ & $14 \%$ \\
\hline Inflation Question & $65 \%$ & $19 \%$ & $73 \%$ & $13 \%$ & $57 \%$ & $26 \%$ \\
\hline Bond Price Question & $28 \%$ & $37 \%$ & $34 \%$ & $29 \%$ & $22 \%$ & $45 \%$ \\
\hline Mortgage Question & $76 \%$ & $15 \%$ & $80 \%$ & $11 \%$ & $72 \%$ & $18 \%$ \\
\hline Risk Question & $53 \%$ & $40 \%$ & $62 \%$ & $31 \%$ & $45 \%$ & $48 \%$ \\
\hline
\end{tabular}

Clearly women underperform men on the individual financial literacy questions, and they underperform men from a holistic perspective, as well. As shown in Table 3, 32\% of women get four or five questions correct compared to $53 \%$ of men. And, on average, women get 2.68 questions correct compared to 3.31 for men.

Table 3

Financial Literacy Quiz Performance

\begin{tabular}{lccc}
\hline & Total & Male & Female \\
\hline Unweighted Sample Size & 28,146 & 13,168 & 14,978 \\
Number of Correct Answers & & & \\
0 & $7 \%$ & $5 \%$ & $9 \%$ \\
1 & $11 \%$ & $7 \%$ & $14 \%$ \\
2 & $17 \%$ & $13 \%$ & $20 \%$ \\
3 & $24 \%$ & $22 \%$ & $25 \%$ \\
4 & $27 \%$ & $32 \%$ & $23 \%$ \\
5 & $15 \%$ & $21 \%$ & $10 \%$ \\
4 or 5 Correct & $42 \%$ & $53 \%$ & $32 \%$ \\
Mean Correct Answers & 2.99 & 3.31 & 2.68 \\
\hline
\end{tabular}

Women's perception of their financial literacy does align with these results. When asked to rate their overall financial knowledge on a 7-point scale, where 1 equals very low and 7 equals very high, women rate themselves, on average, 4.8 compared to men, who rate themselves as 5.1. Further, numeracy has been found 
to be linked to financial decisions (Lusardi 2012). In the NFCS, respondents were asked to rate their mathematical ability. ${ }^{5}$ Female respondents ranked themselves significantly lower than men on this self-assessment- 5.79 for men and 5.36 for women on a 7-point scale where 1 indicates a low self-assessment of mathematical ability and 7 indicates a high self-assessment. These findings taken together-that is, lower financial literacy scores, lower self-assessments of financial knowledge, and lower self-assessments of mathematical ability-suggest that women may be at a disadvantage relative to men when facing challenging financial decisions, including credit card decisions. ${ }^{6}$

Female and male respondents own credit cards in equal numbers, but female respondents exhibited more costly credit card behavior than male respondents (Table 4). For example, women were 5 percentage points more likely to carry a

Table 4

Credit Card Behavior

\begin{tabular}{llll}
\hline Type of Behavior & Total & Male & Female \\
\hline Owns at Least One Credit Card & $75 \%$ & $76 \%$ & $74 \%$ \\
Negative Behaviors & & & \\
\hline Carried a Balance & $58 \%$ & $55 \%$ & $60 \%$ \\
Paid Minimum & $40 \%$ & $38 \%$ & $42 \%$ \\
Late Fee & $26 \%$ & $23 \%$ & $29 \%$ \\
Over the Limit Fee & $16 \%$ & $15 \%$ & $16 \%$ \\
Cash Advance & $13 \%$ & $15 \%$ & $12 \%$ \\
Positive Behaviors & & & \\
Paid Balance in Full & $42 \%$ & $45 \%$ & $39 \%$ \\
Comparison Shopped for Cards & $34 \%$ & $37 \%$ & $31 \%$ \\
Multiple Problematic Behaviors & & & \\
\hline No Problems & $12 \%$ & $14 \%$ & $11 \%$ \\
1 Problem & $31 \%$ & $33 \%$ & $30 \%$ \\
2 Problems & $21 \%$ & $20 \%$ & $22 \%$ \\
3 Problems & $15 \%$ & $15 \%$ & $16 \%$ \\
4 Problems & $10 \%$ & $9 \%$ & $11 \%$ \\
5 Problems & $8 \%$ & $7 \%$ & $8 \%$ \\
Problems & $3 \%$ & $2 \%$ & $3 \%$ \\
More than two problems & $36 \%$ & $33 \%$ & $38 \%$ \\
Credit Score (Self-Reported) & & & \\
620 or Lower & $22 \%$ & $20 \%$ & $25 \%$ \\
630-710 & $27 \%$ & $28 \%$ & $27 \%$ \\
720 or Higher & $42 \%$ & $46 \%$ & $39 \%$ \\
\hline
\end{tabular}

Notes: Respondents who did not report owning credit cards were excluded from this analysis. Not engaging in a positive behavior was coded as a negative behavior for counts of problematic behaviors. Carried a balance and paid balance in full are conceptually and statistically related, so carried a balance was excluded from the count of problematic behaviors. Responses of don't know and prefer not to say were coded as missing, which resulted in sample sizes that differed from question to question--from a low of 19,859 to a high of 20,922. The credit score variable is based on a sample of 11,941 respondents who reported their credit score - given the reduced sample, weights were not used for this variable.

\footnotetext{
${ }^{5}$ Respondents were asked to respond to the statement "I am pretty good at math" using a 7-point scale where 1 equals strongly disagree and 7 equals strongly agree.

${ }^{6}$ All mean-based differences reported in this section are statistically significant at the $1 \%$ level.
} 
balance, 4 percentage points more likely to pay the minimum payment on their cards, and 6 percentage points more likely to be charged a late fee. Similarly, women were 5 percentage points more likely to engage in more than two problematic credit card behaviors and were less likely to engage in positive credit card behaviors-like paying the monthly balance in full and doing comparison shopping for credit cards.

The NFCS also includes data on self-reported credit scores, but only about two in five respondents knew and were willing to report their credit score. The credit score data are reported in Table 4, but given the low response rate to this question, the data should be interpreted cautiously. That said, women are 5 percentage points more likely than men to report a credit score of 620 or lower (i.e., $25 \%$ for men compared to $20 \%$ for women).

The male/female differences in Table 4 are statistically significant at the $1 \%$ significance level, but they are meaningful on a relative basis as well. For example, when considering that only $23 \%$ of male respondents were charged a late fee, the 6 percentage-point increase for women means that women were $26 \%$ more likely than men to be charged a late fee. One bright spot for women, though, is that they were less likely than men to take a cash advance on their credit card, but it is unclear why women outperformed men in this one area.

Credit card behavior also varies significantly by financial literacy levels. Table 5 shows the number of costly credit card behaviors by financial literacy level-with respondents answering four or five of the five questions correctly coded as high financial literacy and respondents answering less than four questions correctly coded as low financial literacy — and a pronounced difference is evident. Forty-two percent of the low financial literacy respondents engaged in more than two costly credit card behaviors compared to $29 \%$ for the high financial literacy group.

Table 5

Credit Card Behavior by Financial Literacy

\begin{tabular}{lcc}
\hline & High Financial Literacy & Low Financial Literacy \\
\hline Costly Credit Card Behaviors & & \\
None & $15 \%$ & $10 \%$ \\
One or Two & $56 \%$ & $49 \%$ \\
More than Two & $29 \%$ & $42 \%$ \\
\hline Note: Respondents answering four or five of the five financial literacy questions correctly \\
were coded as high financial literacy and all other respondents were coded as low financial \\
literacy.
\end{tabular}

There are clearly gender-based differences in credit card behavior, but what role does financial literacy play in explaining these differences? And, do these gender-based differences persist even after controlling for other demographic characteristics? For example, if we could compare men and women who were 
identical in many demographic respects-for instance, income, education level, age, and race-would we still find credit card behavior differences between the sexes?

\section{Credit Card Behavior-Beyond Gender and Financial Literacy}

Two logistic regression analyses were conducted to examine the effect of gender and financial literacy on credit card behavior after controlling for a number of demographic variables. The dependent variable was coded as one if the respondent had more than two costly credit card behaviors and zero otherwise. ${ }^{7}$ Binary variables were created for all but one of the independent variables-with a one indicating the presence of the characteristic and a zero indicating the absence of the characteristic. The independent variables included female, household income less than or equal to $\$ 50,000$, age less than 45 , household experienced an income shock, low financial literacy, dependents in the household, college educated, and a self-assessment of good math skills. Binary variables were created for eight of the nine independent variables because a general rule for logistic regression is that no cells in the factor space should be zero, and $80 \%$ of cells should have more than five observations (Garson 2012). In order to meet this requirement and maximize the number of control variables in the regression, the polytomous independent variables (i.e., independent variables with more than two response categories, like race and marital status) were converted to binary variables, which significantly reduced the number of cells and consequently increased the sample size per cell. The appendix contains a description of each binary variable.

Model 1 in Table 6 shows a simple regression with gender as the only independent variable, and females are estimated to engage in costly credit card behaviors at a rate that is 4 percentage points higher than males. Model 2 in Table 6 includes the control variables - the effect for females drops from 4 percentage points to 1 percentage point and is no longer statistically significant.

Additional findings emerge from this regression, as well. Financial literacy is significantly related to costly credit card behaviors - even after accounting for the effects of key demographic variables. Low financial literacy respondents were nearly 6 percentage points more likely to engage in costly credit card behaviors relative to high financial literacy respondents. The better respondents rated their math skills the less likely they were to engage in costly credit card behaviors.

\footnotetext{
${ }^{7}$ As a robustness check, the dependent variable was recoded as one if the respondent had more than three costly credit card behaviors and zero otherwise. The results obtained from this regression were very similar to the results obtained from the regression reported in this paper.
} 
Table 6

Logistic Regression for Credit Card Behavior

\begin{tabular}{|c|c|c|c|c|}
\hline \multirow[b]{2}{*}{ Variable } & \multicolumn{2}{|c|}{ Model 1} & \multicolumn{2}{|c|}{ Model 2} \\
\hline & Coefficient & $\begin{array}{c}\text { Marginal } \\
\text { Probability }\end{array}$ & Coefficient & $\begin{array}{c}\text { Marginal } \\
\text { Probability }\end{array}$ \\
\hline Female & $\begin{array}{c}0.1851^{* *} \\
(0.029)\end{array}$ & $4.2 \%$ & $\begin{array}{c}0.051 \\
(0.032)\end{array}$ & $1.2 \%$ \\
\hline Low Financial Literacy & & & $\begin{array}{c}0.248 * * \\
(0.034)\end{array}$ & $5.8 \%$ \\
\hline Good Math Skills (self-reported) & & & $\begin{array}{l}-0.059 \\
(0.010)\end{array}$ & $-1.4 \%$ \\
\hline Income Shock & & & $\begin{array}{c}0.668 * * \\
(0.032)\end{array}$ & $15.6 \%$ \\
\hline Age Less Than 45 & & & $\begin{array}{c}0.363^{* *} \\
(0.033)\end{array}$ & $8.5 \%$ \\
\hline Income $\$ 50,000$ or Less & & & $\begin{array}{c}0.375^{* *} \\
(0.033)\end{array}$ & $8.7 \%$ \\
\hline Presence of Dependents in Household & & & $\begin{array}{c}0.520^{* *} \\
(0.033)\end{array}$ & $11.9 \%$ \\
\hline Minority & & & $\begin{array}{c}0.253 \\
(0.035)\end{array}$ & $5.9 \%$ \\
\hline College Educated & & & $\begin{array}{c}-0.293 * * \\
(0.037)\end{array}$ & $-6.8 \%$ \\
\hline Intercept & $-0.688 * *$ & & $\begin{array}{c}-1.236 * * \\
(0.070)\end{array}$ & \\
\hline Observations & 20,922 & & 20,513 & \\
\hline R-Square & 0.002 & & 0.084 & \\
\hline Max-rescaled R-Square & 0.003 & & 0.117 & \\
\hline
\end{tabular}

Notes: Standard errors in parentheses. ${ }^{* *} \mathrm{p}<0.01,{ }^{*} \mathrm{p}<0.05$. Marginal probabilities assume female, age is less than 45 , income is less than or equal to $\$ 50,000$, not college educated, no dependents in the household, not a minority, low financial literacy, average self-assessed math skills, and that the household did not experience an income shock. Collinearity was tested for and not found. Only respondents who indicated that they had one or more credit cards were included in the analysis.

For example, a one standard deviation increase on the 7-point scale used to measure self-assessed math skills (i.e., a 1.6 point increase on the scale) corresponded to about a 3 percentage point decrease in the likelihood of costly credit card behaviors. Households experiencing income shocks were 16 percentage points more likely than households not experiencing shocks to engage in costly credit card behaviors-although this finding may indicate that households grappling with income shocks are making tough but understandable tradeoffs when it comes to paying their bills. For example, for a financially stressed household, making a mortgage payment or buying food may be more important than making a credit card payment. Households with dependents were also more likely to engage in costly credit card behaviors-perhaps an indication of the general financial strains that accompany raising children. And collegeeducated respondents were less likely to engage in costly credit card behaviors. 


\section{Credit Card Interest Rates}

The findings to this point suggest that women engage in more costly credit card behaviors than men, but that this difference can, potentially, be eliminated after controlling for a variety of variables. Another important aspect of credit card usage is the credit card interest rates that men and women pay. Are gender and financial literacy related to credit card interest rates in the same fashion that they are related to credit card management?

To examine this question, OLS regression analyses were conducted with selfreported credit card interest rate as the dependent variable and gender and a set of controls as the independent variables. Only about one in five credit card holders reported the interest rate on their card and their credit score (a control variable). As such, this analysis should only be viewed as exploratory in nature. Table 7 shows the descriptive statistics for the credit card interest rate variable.

Table 7

Descriptive Statistics for Credit Card Interest Rate

\begin{tabular}{lc}
\hline & Credit Card Interest Rate \\
\cline { 2 - 2 } Sample Size & 4,309 \\
Mean & $14.72 \%$ \\
Median & $13.99 \%$ \\
Standard Deviation & $7.14 \%$ \\
Minimum & $0.00 \%$ \\
Maximum & $50.00 \%$ \\
Skewness & 0.31 \\
Kurtosis & -0.37 \\
\hline Notes: Only respondents who reported their credit card \\
interest rate and an estimate of their credit score were \\
included in the analysis. Given the reduced sample, the \\
data were not weighted.
\end{tabular}

The results of the regression analyses are shown in Table 8. Model 1, the model with only gender as the independent variable, shows the uncontrolled-for difference in credit card interest rates between men and women-which is almost 1 percentage point (i.e., 0.82). Model 2 shows the same model with the addition of the control variables. Even after controlling for a host of variables, women pay almost half a percentage point more in credit card interest rates than men. ${ }^{8}$ That said, the overwhelming driver of credit card interest rates is clearly credit score. Respondents with a credit score of 620 or less paid credit card interest rates that were 3.96 percentage points higher than respondents with credit scores above 620 . Respondents experiencing an income shock and low-income respondents also paid higher credit card interest rates.

\footnotetext{
${ }^{8}$ Alesina and Lotti (2013) found that women pay more for credit in Italy.
} 
Table 8

OLS Regression for Credit Card Interest Rate

\begin{tabular}{lccc}
\hline & Model 1 & & Model 2 \\
\cline { 2 - 2 } Variable & Coefficient & Coefficient \\
\hline Female & 0.821 & & $0.448^{*}$ \\
& $(0.203)$ & & $0.204)$ \\
Low Financial Literacy & & 0.197 \\
& & $(0.216)$ \\
Good Math Skills (self-reported) & & -0.107 \\
& & $(0.063)$ \\
Income Shock & & $0.547^{* *}$ \\
& & $(0.205)$ \\
Age Less Than 45 & & 0.300 \\
& & $(0.204)$ \\
Income \$50,000 or Less & & $0.779^{* *}$ \\
& & $(0.217)$ \\
Minority & & 0.225 \\
& & $(0.246)$ \\
Presence of Dependents in Household & & 0.216 \\
College Educated & & $(0.209)$ \\
& & -0.055 \\
Credit Rating 620 or Lower & & $(0.206)$ \\
Intercept & & $3.958^{* *}$ \\
Observations & & $(0.259)$ \\
R-squared & & $12.588^{* *}$ \\
\hline
\end{tabular}

Notes: Dependent variable is self-reported interest rate on card with the largest balance. Robust standard errors are in parentheses. ${ }^{* *} \mathrm{p}<0.01$ and $* \mathrm{p}<0.05$. Six outliers were removed from the analysis because their self-reported credit card interest rates were higher than $50 \%$. Collinearity was tested for and not detected. Only respondents who provided an estimate of their credit card interest rate and credit score were included in the analysis. Given the reduced sample, the data was not weighted.

Although a roughly half-percentage point spread in credit card interest rates between men and women is not a marked difference, over the course of a lifetime a female consumer could pay hundreds or thousands of dollars more in borrowing costs relative to a male with the same demographic characteristics. For example, a half-point difference in credit card interest rates on a balance of $\$ 7,700$ over a lifetime would result in over $\$ 2,000$ in additional borrowing costs. ${ }^{9}$

\section{Conclusion}

These findings suggest that women engage in more costly credit card behaviors than men, but that much-if not all—of the difference can be accounted for by demographic characteristics, economic circumstances (i.e., income shocks), and financial literacy levels. In other words, if we could compare men and women who were identical in many demographic respects, we would not likely find

\footnotetext{
${ }^{9}$ Assumes compounding interest, no additional purchases or payments, and a time period of fifty years.
} 
differences in credit card behavior. However, as is evident from the descriptive analysis earlier in this paper (see Table 1), women and men are not demographically identical. Women tend to have lower income and financial literacy levels - and they are less confident about their math skills. As such, an important implication from this study is that improving characteristics that are mutable-like financial literacy and math skills-may represent the most effective and efficient means of eliminating credit card behavior differences between the sexes.

While exploratory in nature, this study also suggests that women may pay more in credit card interest rates-even after accounting for credit score and a host of control variables. This finding should be interpreted with caution given the limitations of the sample, but it does suggest that additional research may be warranted in this area. For example, perhaps this difference is due in part to the tendency of women to comparison shop for credit cards less than men (FINRA Investor Education Foundation 2009).

Last, while this paper focused on gender and financial literacy, the analyses suggest that other variables may play a much more pronounced role in affecting credit card behavior. For example, respondents reporting a sharp and unexpected drop in income experienced higher levels of costly credit card behaviors, as did low-income respondents and minorities, so additional research focusing on these variables could prove both insightful and useful.

\section{Acknowledgments}

The author would like to thank Chris Bumcrot, Sara Grohl, Tahira Hira, Judy Lin, George Smaragdis, Richard Vagnoni and four anonymous reviewers for their helpful and insightful comments on early drafts of the paper.

\section{References}

Alesina, A., and F. Lotti. 2013. Do women pay more for credit? Evidence from Italy. Journal of European Economic Association 11: 45-66. http://dx.doi.org/10.1111/j.1542-4774.2012.01100.x

Allgood, S., and W. B. Walstad. 2011. The effects of perceived and actual financial knowledge on credit card behavior. Working Paper 2011-WP-15, Networks Financial Institute at Indiana State University, Terre Haute, Indiana.

Bricker, J., A. B. Kennickell, K. B. Moore, and J. Sabelhaus. 2012. Changes in US family finances from 2007 to 2010: Evidence from the Survey of Consumer Finances. Federal Reserve Bulletin, 98(2). 
Collins, M. 2012. Financial advice: A substitute for financial literacy? Financial Services Review 21(4): 307-322.

Fonseca, R., K. J. Mullen, G. Zamarro, and J. Zissimopoulos. 2012. What explains the gender gap in financial literacy? Journal of Consumer Affairs 46 (1): 90-106. http://dx.doi.org/10.1111/j.1745-6606.2011.01221.x

Knoll, M., and C. Houts. 2012. The financial knowledge scale: An application of item response theory to the assessment of financial literacy. Journal of Consumer Affairs 46(3): 381-410.

http://dx.doi.org/10.1111/j.1745-6606.2012.01241.x

FINRA Investor Education Foundation. 2009. Financial capability in the United States.

Garson, D. G. 2012. Testing statistical assumptions. Asheboro, NC: Statistical Publishing Associates.

Lachance, M.-E., and N. Tang. 2012. Financial advice and trust. Financial Services Review 21(3): 209-226.

Lusardi, A. 2011. American's financial capability. PRC Working Paper WP201102, Pension Research Council, Philadelphia, PA.

—. 2012. Numeracy, financial literacy and financial decision-making. Numeracy 5(1). http://dx.doi.org/10.5038/1936-4660.5.1.2

Lusardi, A., and O. Mitchell. 2008. Planning and financial literacy: How do women fare? American Economic Review 98(2): 414-417. http://dx.doi.org/10.1257/aer.98.2.413

- 2011a. Financial literacy and retirement planning in the United States. Journal of Pension Economics and Finance 10(4): 509-525. http://dx.doi.org/10.1017/S147474721100045X

- 2011b. Financial literacy around the world: An overview. Journal of Pension Economics and Finance 10(4): 497-508. http://dx.doi.org/10.1017/S1474747211000448

—. 2011c. Financial literacy and planning: Implications for retirement wellbeing. In Financial literacy: Implications for retirement security and the financial marketplace, ed. O. S. Mitchell and A. Lusardi, 17-39. Oxford, UK: Oxford University Press. http://dx.doi.org/10.1093/acprof:oso/9780199696819.003.0002

Lusardi, A., and P. Tufano. 2009. Debt literacy, financial experiences, and overindebtedness. NBER Working Paper 14808, National Bureau of Economic Research, Cambridge, MA.

Robb, C., and A. Woodyard. 2011. Financial knowledge and best practice behavior. Journal of Financial Counseling and Planning 22(1): 60-70.

Robb, C., P. Babiarz, and A. Woodyard. 2012. The demand for financial professionals' advice: The role of financial knowledge, satisfaction, and confidence. Financial Services Review 21(4). 
Stango, V., and J. Zinman. 2009. Exponential growth bias and household finance. Journal of Finance 64: 2807-2849. http://dx.doi.org/10.1111/j.1540-6261.2009.01518.x

US Census Bureau, Statistical Abstract of the United States: 2012 (131st Edition) Washington, DC, 2011

van Rooij, M., A. Lusardi, and R. Alessie. 2011. Financial literacy and stock market participation, Journal of Financial Economics 101(2): 449-472. http://dx.doi.org/10.1016/j.jfineco.2011.03.006

Yoong, J. 2011. Financial illiteracy and stock market participation: Evidence from the American Life Panel. In Financial literacy: Implications for retirement security and the financial marketplace, ed. O. Mitchell and A. Lusardi, 76100, Oxford, UK: Oxford University Press. http://dx.doi.org/10.1093/acprof:oso/9780199696819.003.0005

\section{Appendix}

Descriptions of binary variables used in the regression analyses.

Female

Coded as 1 if respondent indicate they were a female and 0 otherwise

Household income less than or equal to $\$ 50,000$

Coded as 1 if household income was less than or equal to $\$ 50,000$ and 0 otherwise

Age less than 45

Coded as 1 if respondent's age was less than 45 and 0 otherwise

Income shock

Coded as 1 if respondent indicated that their household experienced an income shock in the 12 months preceding the survey and 0 otherwise

Low financial literacy

Coded as 1 if the respondent answered 0 through 3 of the 5 financial literacy

questions correctly and 0 if they answered 4 or 5 correctly

Minority

Coded as 0 if the respondent indicated they were White or Caucasian and 1 otherwise

Dependents in household

Coded as 1 if the respondent indicated that have at least one financial dependent in the household and 0 otherwise

\section{College}

Coded as 1 if the respondent indicated they were a college graduate or had post graduate education 